\title{
STAPHYLOCOCCUS SP. STRAIN MY 83295F: A POTENTIAL P,P'-DDT-DEGRADING BACTERIUM ISOLATED FROM PESTICIDE CONTAMINATED SOIL
}

\author{
Ya'u MURTALA ${ }^{1,2 *}$, Bennett C NWANGUMA ${ }^{2}$, Lawrence US EZEANYIKA ${ }^{2}$ \\ ${ }^{1}$ Department of Biochemistry, Faculty of Basic Medical Sciences, Bayero University, Kano \\ ${ }^{2}$ Department of Biochemistry, Faculty of Biological Sciences, University of Nigeria, Nsukka
}

\begin{abstract}
*Correspondence:
Ya'u MURTALA

myau.bch@buk.edu.ng
\end{abstract}

Received: 26 August 2020; Accepted: 05 November 2020; Published: 30 December 2020

\begin{abstract}
Although DDT has been on the ban list by the Stockholm Convention for its environmental degradation, still a wave of emerging shreds of evidence has proved its circulation in developing countries. The intensity of environmental degradation and human health problems posed by residual DDT and its metabolites become of serious ecological concern, warranting a search for novel strains with a capacity to biodegrade these environmental contaminants. A new strain of the genus Staphylococcus was isolated from pesticide-contaminated soil. The 16S rRNA and phylogenetic analyses were used to identify the isolate and the 16S rRNA partial gene sequence was deposited in the NCBI GenBank as Staphylococcus sp. strain MY $83295 \mathrm{~F}$. The isolate was capable of growing in up to $60 \mathrm{mg} \mathrm{L}^{-1}$ of $p, p^{\prime}$-DDT as the sole carbon source at an optimum $\mathrm{pH}$ of 6.5 and optimum temperature of $30^{\circ} \mathrm{C}$ within $120 \mathrm{~h} . \mathrm{Zn}^{2+}$ has demonstrated a stimulatory effect on the growth of the strain in p,p'-DDT containing medium. However, $\mathrm{Fe}, \mathrm{Cu}, \mathrm{Pb}, \mathrm{Hg}, \mathrm{Ag}$, and $\mathrm{Cr}$ ions showed inhibitory effects on the strain's growth in the medium. The strain could be a handy tool for the bio-cleansing of residual $p, p$ '-DDT in the contaminated environment.
\end{abstract}

Keywords: DDT biodegradation, Staphylococcus, 16S rRNA, pesticide contaminant, heavy metals.

\section{Introduction}

Among the most notorious and persistent agrochemical environmental contaminants, the dichlorodiphenyltrichloroethane (DDT) still occupies a prominent position in the ranking of the hazardous environmental pollutants. This arises due to its persistence and potential accumulation in both biotic and abiotic components of the ecosystem (Bussolaro et al., 2012; Devi, 2020). Although DDT and other Persistent Organic Pollutants (POPs) have been on the ban list by the Stockholm Convention for their environmental degradation capacity,
DDT is, still in circulation in developing countries (Abdul Kader, 2019). A comprehensive report released by the United Nations Environmental Protection (UNEP) on the current status of DDT from 2015 to 2017 in developing countries indicated that India, Mozambique, South Africa, and Zimbabwe reported the use of DDT (UNEP, 2019). While Botswana, Eswatini, Ethiopia, Eritrea, Madagascar, Marshall Islands, Namibia, Uganda, Venezuela, and Zambia have refused to give any response on the status of the use of 
DDT between 2015-2017, despite all the efforts by the UNEP. This perhaps signals the use of DDT for vector control in these countries (UNEP, 2019).

It was documented that in Nigeria several tons of chlorinated pesticides are used every year for both agriculture and disease-borne control (Asogwa and Dongo, 2009), and consequently, remnants of DDT were recently traced in domestic water samples (Ogbeide et al., 2015). Many studies across the world have reported the traces of DDT in ambient air, domestic water, and various food sources (Bussolaro et al., 2012; Mendes et al., 2019; Thompson et al., 2019). The levels of DDT reported in many food items exceeded the tolerable daily limits stated by the U.S. Environmental Protection Agency (Sheldon et al., 2019).

DDT and its metabolites such as dichlorodiphenyldichloroethylene (DDE) have been implicated in many health-related problems. They were reported to be linked to endocrine disruption (Mnif et al., 2011; Piazza and Urbanetz, 2019). Truong et al. (2019) reported an association between DDT metabolites and long-term impairments of muscle health. Many studies have established the probable involvement of DDT in cancer induction (Hadara et al., 2016; Cohn et al., 2019). DDT was also documented to induce cognitive decline and alteration in maternal metabolomes (Medehouenou et al., 2019; Hu et al., 2019). Yu et al. (2019) demonstrated that DDT is associated with some risks of triggering apoptosis of skin fibroblast in some aquatic animals.

From the beginning of the last decade to date, many bacterial strains have been identified to degrade DDT and its metabolites; DDD and DDE (Fang et al., 2010; Hug et al., 2013; Wang et al., 2017; Pan et al., 2017; Xie et al., 2018). The microbial ability to degrade DDT have strengthened the hope of employing them in the bioremediation of DDT contaminated sites.

Although DDT degradation was reported to be a multistep process (Fang et al., 2010; Cutright and Erdem, 2012), it mostly occurs either through aerobic or anaerobic metabolism. With favourable conditions, suitable strains were shown to degrade DDT to 4-chlorobenzoic acid (4-CBA) aerobically or to 4,4-dichlorobenzophenone (4-DBP) under anaerobic conditions (Nadeau et al., 1998; Baczynski et al., 2010; Gao et al., 2011; Bao et al., 2012). Alcaligenes sp. and Serratia marcaescens DT-1P were reported to degrade DDT to 4-CBA aerobically via the DDE metabolic pathway in the presence of additional carbon sources (Bidlan and Manonmani, 2002). However, DDT was shown to be rapidly degraded anaerobically to 4-DBP through the DDD reductive dechlorination pathway (You et al., 1996; Baczynski et al., 2010; Fang et al., 2010).

The intensity of environmental degradation and human health problems posed by DDT and its metabolites, particularly their persistent nature in the environment, searching a microbial community for novel strains with a capacity to bio-clean the environment is pertinent. This work was focused on the isolation and characterization of $p, p^{\prime}$-DDTdegrading bacterium from the tropical contaminated soil.

\section{Materials and Methods}

\subsection{Sample collection}

A soil sample was collected from irrigation sites located at Phase I, Kadawa Irrigation Site, Hadejia-Jama'are River Basin, Kano State with a history of continued agrochemical farming activities for more than three decades. The sample was collected at the surface of the soil to the depths of $15 \mathrm{~cm}$. The sampling was focused on these horizons because a large 
portion of microbial activity occurs in these horizons. The soil sample was mixed evenly and $20 \mathrm{~g}$ was carefully put into a sterile container and taken to the laboratory at $4{ }^{\circ} \mathrm{C}$ for bacterial isolation.

\subsection{Preparation of media for bacterial growth}

The Luria-Bertani medium (LB) was used for the bacterial growth.

\subsection{Preparation of $p, p$ '-DDT-minimal salt enrichment medium (MSM)}

The Minimal Salt Medium (MSM) had the following composition as described by Pant et al. (2013) with some modifications: per litre of distilled water, $0.1 \mathrm{~g} \mathrm{CaCl} 2.2 \mathrm{H}_{2} \mathrm{O}, 0.08 \mathrm{~g}$ $\mathrm{Ca}\left(\mathrm{NO}_{3}\right)_{2} \quad 4 \mathrm{H}_{2} \mathrm{O}, 0.5 \mathrm{~g} \mathrm{MgCl}_{2} .6 \mathrm{H}_{2} \mathrm{O}, 1.0 \mathrm{~g}$ $\mathrm{Na}_{2} \mathrm{SO}_{4}$ and $1.0 \mathrm{~g} \mathrm{KH}_{2} \mathrm{PO}_{4}$ were dissolved. Then before inoculation, MSM was enriched with $p, p$ '-DDT $\left(0.05 \mathrm{mg} \mathrm{mL}^{-1}\right)$. The $p, p^{\prime}$-DDTMSM contains $p, p$ '-DDT as the only carbon source for the bacterial growth. Thus, growth in this media depends only on the strain's ability to metabolize the $p, p$ '-DDT pesticide.

\subsection{Isolation of $p, p$ '-DDT-degrading bacterium from soil samples}

Isolation of strain MY 83295F was carried out using a modified isolation procedure described by Pant et al. (2013). Air-dried soil $(0.5 \mathrm{~g})$ was suspended in $20 \mathrm{~mL}$ of the prepared LB medium. The suspension was kept for $48 \mathrm{~h}$ at $30^{\circ} \mathrm{C}$ on a shaker. After the incubation, the LB medium was allowed to settle down for $2 \mathrm{~h}$. An aliquot $(150 \mu \mathrm{L})$ from the cleared LB supernatant was used to inoculate $6 \mathrm{~mL}$ of $p, p$ 'DDT enrichment MSM. The culture was then incubated for 1 week at $30^{\circ} \mathrm{C}$ on a rotary shaker at $100 \mathrm{rpm}$. After incubation, $100 \mu \mathrm{L}$ of the bacterial suspension was transferred into $4 \mathrm{~mL}$ of fresh $p, p$ '-DDT enriched MSM and the incubation step was repeated. After four sequential cultivations, the isolate was inoculated on to MSM agar plates enriched with $0.05 \mathrm{mg} \mathrm{mL}^{-1}$ of $p, p^{\prime}$-DDT and incubated for $72 \mathrm{~h}$ at $30^{\circ} \mathrm{C}$ and the isolate formed was preserved. This ensures adequate exposure of the isolate to the $p, p^{\prime}$-DDT as a sole carbon source.

\subsection{Extraction of genomic DNA}

A single loop of the isolate was used to inoculate $8 \mathrm{~mL}$ of $\mathrm{LB}$ medium. Followed by incubation at $37^{\circ} \mathrm{C}$ and $200 \mathrm{rpm}$ for $24 \mathrm{~h}$. The bacterial suspension $\left(\mathrm{OD}_{600 \mathrm{~nm}}=0.6\right)$ formed was centrifuged for $5 \mathrm{~min}$ at $10,000 \mathrm{rpm}$. Then the bacterial DNA was extracted following the protocol stated by Schmidt et al. (1991).

\subsection{S ribosomal RNA gene (16S rRNA) amplification}

To amplify $\sim 1.5 \mathrm{~Kb}$ gene from the isolated genomic DNA, 16S rRNA gene primers (BAC27F and BAC1492R) [16SRNA BAC27F: 5'-AGA GTT TGA TCC TGG CTC AAG-3' and 16SRNA BAC1492R: 5'- GGT TAC CTT GTT ACG ACT T-3'] purchased from Sigma-Aldrich, United Kingdom, were used (Sangwan et al., 2005). The PCR was carried out using TC-E-48FA Gene Touch Thermocycler, Hangzhou Bioer Technology, (China). The total reaction volume was $15 \mu \mathrm{L}$, in which the reaction mix comprises of $1 \mu \mathrm{L}$ of the genomic DNA, $1.5 \mu \mathrm{L}$ of $10 \mathrm{X}$ TaqA buffer, $0.5 \mu \mathrm{L}$ of each of $10 \mu \mathrm{M}$ forward and reverse primers, $0.75 \mu \mathrm{L}$ of $1.25 \mathrm{mM}$ of $\mathrm{MgCl}_{2}, 0.15$ $\mu \mathrm{L}$ of $0.25 \mathrm{mM}$ of $\mathrm{dNTP}$ and $0.12 \mu \mathrm{L}$ of Taq DNA polymerase in $\mathrm{ddH}_{2} \mathrm{O}$. The PCR protocol was set as follows: the initial melting temperature was $95^{\circ} \mathrm{C}$ for $5 \mathrm{~min}, 35$ cycles each at melting temperature of $94^{\circ} \mathrm{C}$ for 0.5 min. The annealing temperature was $52^{\circ} \mathrm{C}$ for $0.5 \mathrm{~min}$ and extension at $72^{\circ} \mathrm{C}$ for $1 \mathrm{~min}$. The final elongation was set for $10 \mathrm{~min}$ at $72^{\circ} \mathrm{C}$.

After the final elongation cycle, the size of the DNA fragment was compared with the Hyper Ladder-1K marker Bioline (Lot No: H4- 
111B). Then 3 of the $\mu \mathrm{L}$ PCR product was mixed with 5XDNA loading buffer blue (1.5 $\mu L$ ) Bioline (Lot No: hLBB-415704) and loaded onto $1.5 \%$ agarose gel electrophoresis that has been stained with ethidium bromide. The electrophoresis was run for 35 min under $120 \mathrm{~V}$ and $300 \mathrm{~mA}$ current. The product was then visualized with the Syngene Gel Documentation System of Ingenius, England (IG31459). The presence of a product of the expected size was considered to be a positive result.

\subsection{Agarose gel purification and sequencing of amplified 16S rRNA gene}

The gel was purified using the PrepEase gel purification kit (Affymetrix inc., USA) by following the manufacturer's protocol. The gelpurified product was sequenced using the protocols described by Sanger et al. (1977). Then, DNA sequence alignment was carried out using the ClustalW 2.0.12 version (http://www.clustal.org/). The sequence was then blasted in the National Center for Biotechnology Information (NCBI) nucleotide databases to identify the organism. The sequence was deposited in the NCBI GenBank under the accession number MN812290.

\subsection{Phylogenetic analysis of the isolates}

Phylogeny and evolutionary history of strain MY 83295F were constructed using the Neighbor-Joining method. The evolutionary distances were computed using the Maximum Composite Likelihood method (Tamura et al., 2013). The phylogenetic tree was constructed using MEGA version 6 software program.

2.9 Characterization of the isolate in minimal salt- $p, p$ '-DDT enrichment medium

During the characterization of the strain MY $83295 \mathrm{~F}$ in the $p$ ' $p$-DDT enrichment medium, we have determined the optimum $p, p$ '-DDT concentration (as a sole carbon source), $\mathrm{pH}$, temperature and incubation time. The characterization was performed by modifications of the methods described by Mwangi et al. (2010) and Pant et al. (2013). The isolate's capacity to grow in the $p, p$ '-DDT enrichment medium was determined in vitro after adjusting the $\mathrm{OD}_{600 \mathrm{~nm}}$ of cell density of the inoculum source to 0.6. The inoculum (150 $\mu \mathrm{L})$ was then inoculated into $4 \mathrm{~mL}$ of MSM media containing varying concentrations $p, p^{\prime}-$ DDT $\left(10,20,30.4050,60\right.$ and $\left.70 \mathrm{mgL}^{-1}\right)$ at various $\mathrm{pH}$ values $(5.5,6.0,6.5,7.0,7.5,8.0$ and 8.5) and incubated at different temperatures $\left(20,25,30,35,40\right.$ and $\left.45^{\circ} \mathrm{C}\right)$ under shaking (150 rpm) at different incubation periods of 24, 48, 72, 96, 120, 144 and $168 \mathrm{~h}$. The experiments were conducted one factor at a time in triplicate.

\subsection{Effects of heavy metals on $p, p$ '-DDT utilization capacity of the isolates}

The effect of each heavy metals ( $\mathrm{Fe}, \mathrm{Zn}, \mathrm{Cu}$, $\mathrm{Pb}, \mathrm{Hg}, \mathrm{Ag}$ and $\mathrm{Cr}$ ) on $p, p$ '-DDT degrading capacity of the strain MY $83295 \mathrm{~F}$ was determined in vitro after adjusting the $\mathrm{OD}_{600 \mathrm{~nm}}$ of cell density of the inoculum source to 0.6, the cells $(100 \mu \mathrm{L})$ were then inoculated into MSM-DDT enrichment media containing varying metal concentrations $(0.2,0,4,0.6,0.8$ and $\left.1.0 \mathrm{mgL}^{-1}\right)$ and incubated on a rotary shaker $(150 \mathrm{rpm})$ at $30{ }^{\circ} \mathrm{C}$ and $\mathrm{pH} 6.5$ for 168 h. This protocol is a modified version of the procedure described by Sandrin and Maier, (2003).

\section{Results and discussions}

In In this study, minimal salt- $p, p$ '-DDT enrichment medium was used for the isolation and screening of $p, p$ '-DDT bio-degrader bacterial strain that used $p, p^{\prime}$-DDT as the sole carbon and energy source obtained from pesticide-contaminated agricultural soil. The biodegradation capacity of $p, p$ '-DDT by the isolate was indicated by the formation of 
turbidity as the index of the biomass formed in the minimal salt- $p$, $p$ '-DDT enrichment medium (Mwangi et al., 2010; Pant et al., 2013).

Staphylococcus sp. strain MY 83295F was found to be a Gram-positive, non-sporeforming, non-motile, catalase-positive, urease, and cytochrome oxidase negative cocci. However, the strain was found to ferment Dglucose, starch and D-mannitol while negative with xylose and indole (data not presented here). A substantial literature on the phenotypic and biochemical characteristics of the genus Staphylococcus showed clear similarities with the above-mentioned characteristics of strain MY 83295F (Bascomb and Manafi, 1998; Khattak et al., 2015; Karmaker et al., 2016).

The 16S rRNA gene sequencing was found to maintain reasonable accuracy and reliability for bacterial identification (Roy et al., 2013; Hong and Farrence, 2015). Thus, for the molecular identification of this isolate to confirm the preceding phenotypic and biochemical identifications, the $16 \mathrm{~S}$ rRNA gene was amplified. The amplification product for the isolate revealed about $1500 \mathrm{bp}$ upon running on $1.5 \%$ agarose gel electrophoresis
(Fig. 1.). Many researchers have earlier reported similar ranges of $16 \mathrm{~S}$ rRNA gene amplification products between the ranges of 1200-1500 bp for the genera Staphylococcus depending on the species, segment amplified or the type of primers used (Saruta et al., 1997; Jill and Clarridge, 2004; Mitra and Roy, 2010).

The 16S rRNA gene amplicon was successfully sequenced, revealing 1057 bp as the partial gene sequence for the strain MY 83295F. The sequence was blasted in the NCBI GenBank that revealed the genus of the strain as Staphylococcus. The 16S RNA gene partial sequence was deposited in public databases of the National Center for Biotechnology Information (NCBI) GenBank as Staphylococcus sp. strain MY 83295F under the universal accession number MN812290.

The BLAST search on strain MY 83295F showed about $80 \%$ of the first hundred representatives were of the genus Staphylococcus, revealing the highest sequence similarity of $99.53 \%$ with Staphylococcus hominis subsp. novobiosepticus strain GTC 1228, followed by Staphylococcus hominis strain DM 122 with $99.15 \%$.

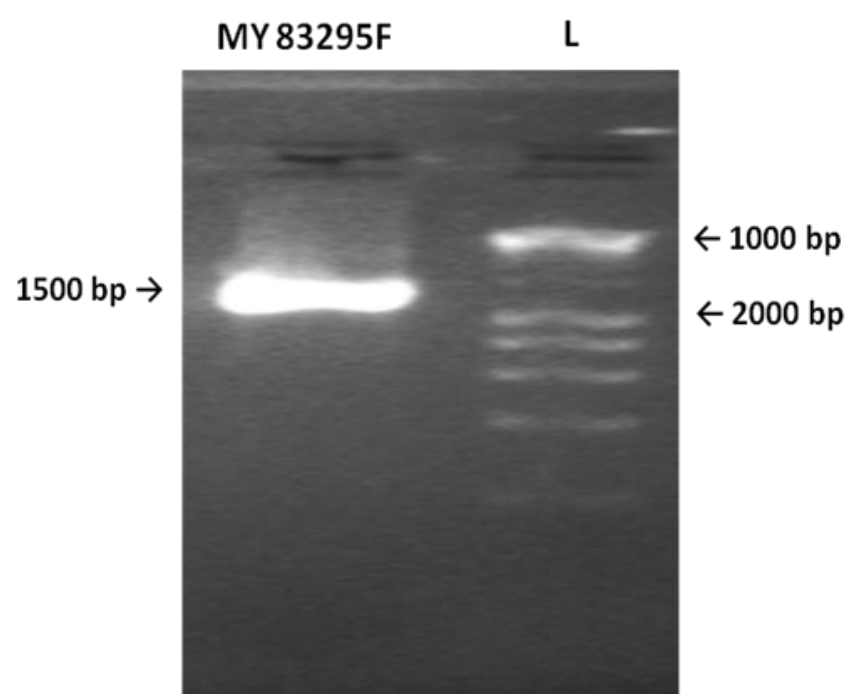

Fig. 1. Agarose gel electrophoretic image of the 16S rRNA amplicon of MY 83295F strain. The gene was amplified using BAC27F and BAC1492R as forward and reverse primers respectively. L represents Hyper Ladder-1K marker Bioline (Lot No: H4-q111B) 
The least \% sequence similarity of $95.27 \%$ was found in Staphylococcus agenesis strain M4S-6 among the representatives of the genus Staphylococcus. The phylogeny and evolutionary analysis revealed a single clade of Staphylococcus hominis strain DM 122 and a cluster of strain MY 83295F and Staphylococcus hominis subsp. novobiosepticus strain GTC 1228 with a bootstrap value of $85 \%$, indicating a closer relatedness of these organisms. However, the cluster of strain MY 83295F and Staphylococcus hominis subsp. novobiosepticus strain GTC 1228 indicated a bootsrap value of $59 \%$ (Fig. 2.). This value is very low to state with certainty that strain MY $83295 \mathrm{~F}$ belongs to the same subspecies with Staphylococcus hominis subsp. novobiosepticus strain GTC 1228. Perhaps, suggesting a new subspecies within the group of Staphylococcus hominis. Therefore, strain MY 83295F was tentatively designated as Staphylococcus sp. strain MY 83295F, where the sp. indicates an unclassified species of this strain, subject to indepth taxonomical approach. Several studies on the identification and taxonomy of the genus Staphylococcus have reported a similar approach in the identification and grouping of Staphylococcal species (Stackebrandt and Goebel, 1994; Takahashi et al., 1999; Ghebremedhin et al., 2008; Naushad et al., 2016).

Microorganisms are vital tools for the removal of various toxic contaminants including the persistent chlorinated pollutants such as DDT from the environment (Reineke et al., 2011). Biodegradation of DDT by bacteria has been well documented, and DDT-degraders have been isolated (Mwangi et al., 2010; Pan et al., 2016). Strain MY $83295 F$ was found to biodegrade and utilize $p, p$ '-DDT as sole carbon and energy source. Though some bacterial species were reported to tolerate $<20 \mathrm{mgL}^{-1}$ of $p, p$ '-DDT as sole carbon and energy (Pant et al., 2013; Pan et al., 2016), strain MY 83295F, however, demonstrated higher tolerance and utilization capacity of up to $60 \mathrm{mg} \mathrm{L}^{-1}$ of $p, p^{\prime}-$ DDT as the sole carbon source under aerobic condition (Fig. 3a).

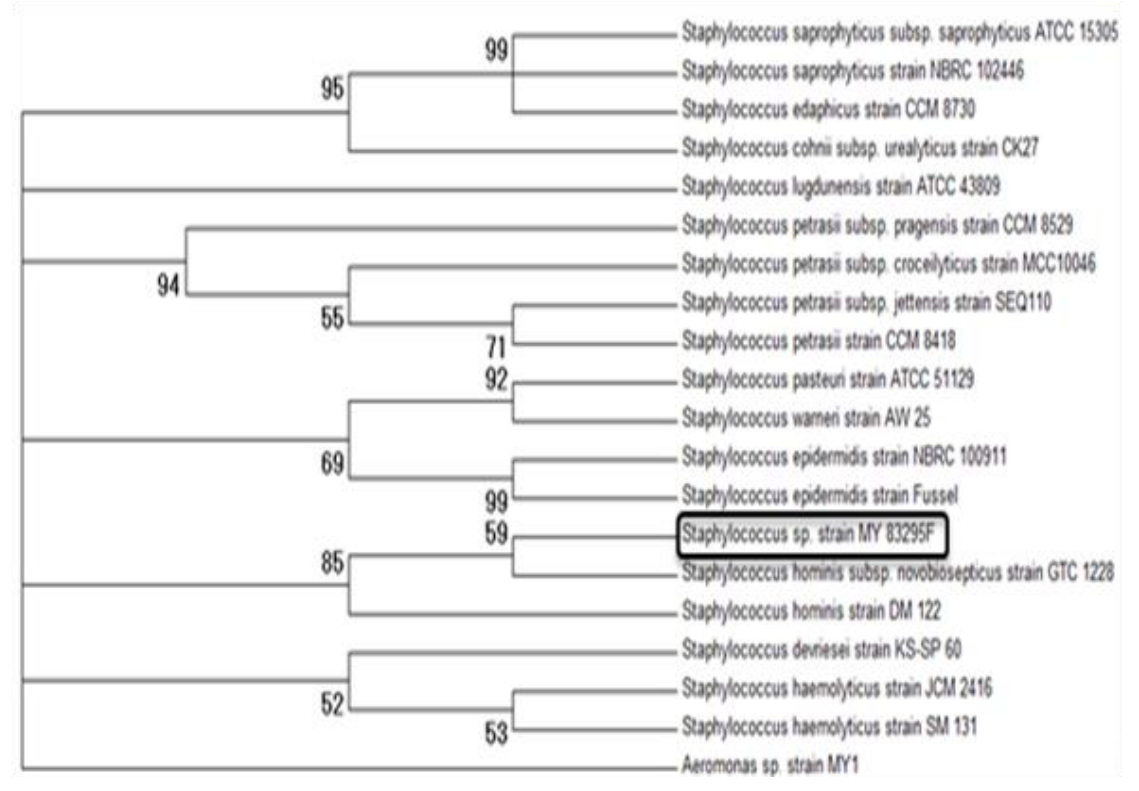

Fig. 2. Phylogenetic and Evolutionary relationships of taxa of strain MY 83295F. The strain's evolutionary position was indicated in a rectangular box. The evolutionary history was inferred using the Neighbor-Joining method. 

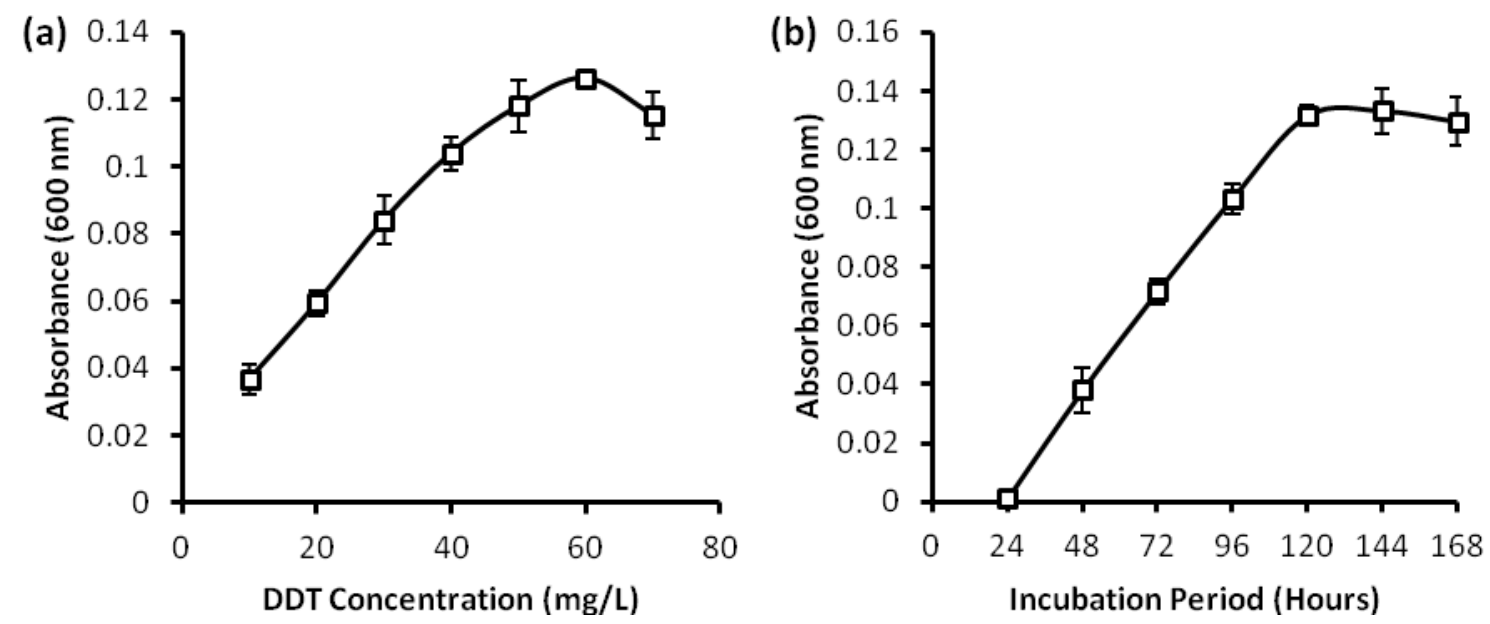

Fig. 3. Effects of $p, p$ '-DDT concentration (a) and incubation time (b) on the growth of strain MY $83295 \mathrm{~F}$ in $p, p$ '-DDT enrichment medium. For determination of the effect of the incubation time on the growth of the strain, $60 \mathrm{mgL}^{-1}$ of $p, p^{\prime}$-DDT was used. The turbidity of the medium is an index

of growth of the isolate in the $p, p^{\prime}$-DDT enrichment medium, which was determined spectrophotometrically as optical density (OD) at $600 \mathrm{~nm}$. The experinments were conducted in triplicate.

Some isolates were also documented to tolerate up to $50 \mathrm{mgL}^{-1}$ of DDT when other carbon sources were supplemented (Kantachote et al., 2003; Barragan-Huerta et al., 2007; Fang et al., 2010).

The ability of a microorganism to depend on DDT as a carbon source depends on the organism's capacity to mineralize the DDT and obtain energy from the process (Fang et al., 2010; Pan et al., 2016). Strains MY 83295F demonstrated longer lag phases of nearly $48 \mathrm{~h}$ for the initial DDT degradation (Figure 3b). The delay observed in the initial rate of DDT degradation in the strain could be attributed to the delay in the production of enzyme machinery for the degradation. However, the strain was able to moderately biodegraded and utilized $p, p$ '-DDT, precipitating total biomass of $0.130\left(\mathrm{OD}_{600 \mathrm{~nm}}\right)$ in $120 \mathrm{~h}$ (Fig. 3b).

As a complex process, bacterial DDT mineralization is largely influenced by some environmental determinants such as $\mathrm{pH}$, temperature and DDT concentration (Aislabie et al., 1997; Bidlam and Manonmani, 2002). Optimization of these parameters is therefore critical for the application of a microbial entity for the DDT biodegradation. Strain MY $83295 \mathrm{~F}$ demonstrated a mesophilic behaviour by exhibiting $p, p$ '-DDT degradation within a wide range of temperatures between $20-45^{\circ} \mathrm{C}$. However, strain MY $83295 \mathrm{~F}$ showed an optimum temperature of $30^{\circ} \mathrm{C}(\mathbf{F i g}$. 4a). This is not surprising by considering the environmental conditions of the tropical region where this strain was isolated. A fluctuation in temperature, either below or above the optimum value, the strains' DDT degradation capacity is lowered.

Strain MY 83295F showed growth capacity in $p, p$ '-DDT enrichment media in both slightly acidic and alkaline conditions, with initial $\mathrm{pH}$ ranging from 5.5 to 7.5. However, the strain demonstrated an optimum $\mathrm{pH}$ of 6.5 (Fig. 4b). A substantial literature has reported an optimal bacterial DDT degradation within a range of $\mathrm{pH}$ close to neutral and temperature range around $30^{\circ} \mathrm{C}$ that correspond to those shown by this strain (Mwangi et al., 2010; Fang et al., 2010; Pan et al., 2016; Raju and Bidlan, 2018). 

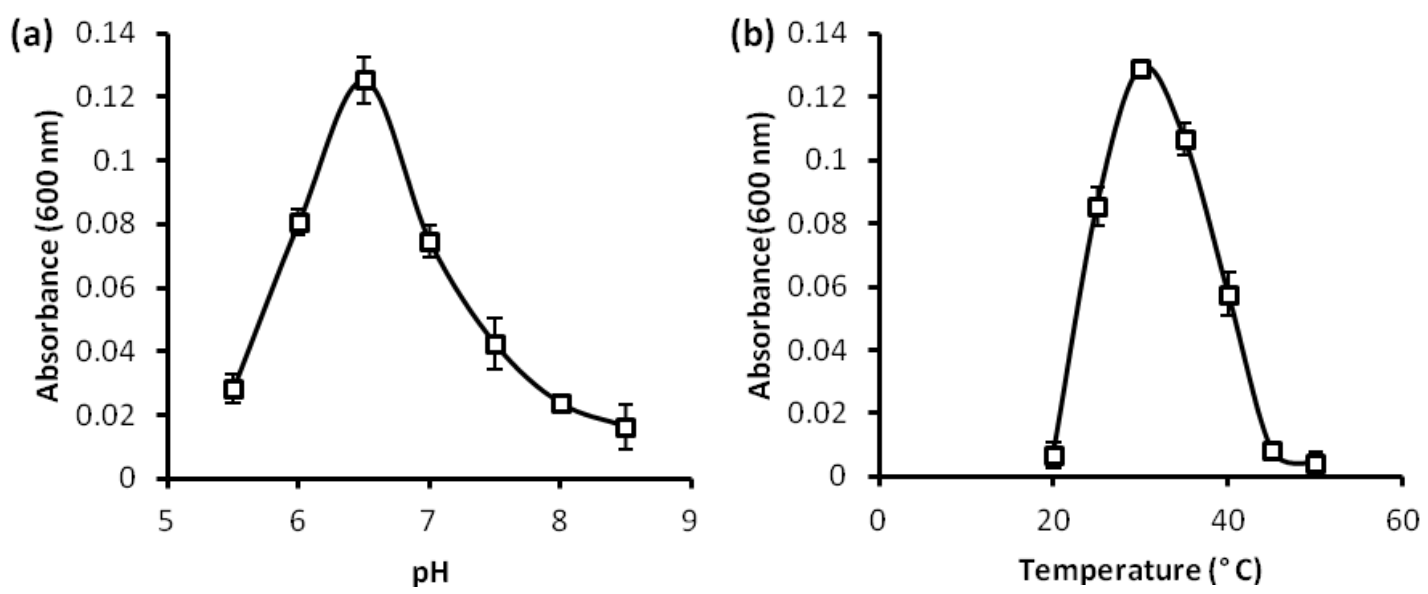

Fig. 4. Effect of $\mathrm{pH}$ (a) and temperature (b) on the growth of strain MY 83295F in p,p'-DDT(60 $\mathrm{mgL}^{-1}$ ) enrichment medium. The turbidity of the medium is an index of growth of the isolate in the $p, p$ '-DDT enrichment medium, which was determined spectrophotometrically as optical density (OD) at $600_{\mathrm{nm}}$. The experinments were conducted in triplicate.

In biological systems, including microorganisms, $\mathrm{pH}$ plays a significant role in changing the ionic character of the constituent amino acids in enzymes and other intracellular and membrane proteins. This perhaps, influences DDT degradation capacity of this bacterial strain, either by affecting the DDT membrane transport system or degradation enzymes.

In most cases, organic pollutants such as DDT and heavy metals co-contaminate the environment, and more or less, the later might influence the degradation rate of the former as reported by Lovecke et al. (2015). The effects of heavy metals on DDT degradation capacity of strain MY 83295F showed both stimulatory and inhibitory effects. Only $\mathrm{Zn}^{2+}$ at $0.2 \mathrm{mgL}^{-1}$ has demonstrated enhancement effect on $p, p$ 'DDT degradation in Staphylococcus sp. strain MY 83295F, precipitating an increase in the biomass in $p, p$ '-DDT enrichment medium after $168 \mathrm{~h}$. An increase in the $\mathrm{Zn}^{2+}$ concentration above $0.2 \mathrm{mgL}^{-1}$ showed a dramatic decline in $p, p$ '-DDT degradation, and reduction in the total biomass of the strain MY 83295F (Fig. 5).

$\mathrm{Zn}^{2+}$ is physiologically essential for bacterial growth. It serves as a cofactor for many microbial metalloenzymes and other structural and regulatory functions. Bacteria have systems called cation diffusion facilitator (CDF) proteins that modulate their survival in the $\mathrm{Zn}^{2+}$ contaminated environment (Guffanti et al., 2012). These bacterial proteins are responsible for $\mathrm{Zn}^{2+}$ homeostasis via $\mathrm{Zn}^{2+}$ uptake/import and $\mathrm{Zn}^{2+}$-efflux/export mechanisms (Suryawati, 2018). The genus Staphylococcus was reported to have these CDF proteins (Nies, 2003).

Thus, Staphylococcus sp. strain MY $83295 \mathrm{~F}$ might have very active $\mathrm{Zn}^{2+}$ homeostasis systems that warrant growth enhancement in the $\mathrm{Zn}^{2+}-p$, $p$ '-DDT enrichment medium. Indeed, the DDT degradation enzyme machinery might interact with the divalent ion such as zinc as presented by Mansouri et al (2017), leading to the enhancement of catalytic ability by the enzyme machinery.

A pattern of inhibition demonstrated by $\mathrm{Fe}^{2+}, \mathrm{Cu}^{2+}$ (Fig. 6a and b) was more favourable to the growth of the strain $83295 \mathrm{~F}$ relative to that of $\mathrm{Pb}^{2+}$ (Fig. 7a), $\mathrm{Hg}^{2+}$ (Fig. 7b) $\mathrm{Ag}^{2+}$ (Fig. 8a) and $\mathrm{Cr}^{2+}($ Fig. 8b). This could be linked to the essentiality of $\mathrm{Cu}^{2+}$ for some metabolic processes in bacteria. However, it has been observed that presence of both organic and metal pollutants resulted in metal toxicity in 
bacteria, mostly by interacting and inhibiting the bacterial enzymes and thus, inhibiting organic pollutant biodegradation (Angle and Chaney, 1989; Sandrin and Maier, 2003; Murata et al., 2005). Also, metal oxyanions, such as chromate, mimic the structure of essential non-metal oxyanions, such as sulfate, and interfere with their biological functions (Sandrin and Maier, 2003). Furthermore, mercuric and silver cations form strong toxic complexes which make them dangerous for any physiological functions, in addition to their inhibitory binding to the $\mathrm{SH}$ group of the variety of bacterial proteins (Nies, 1999). Metal ions generally affect organic biodegradation by altering both the physiology and ecology of the organic bio-degraders (Sandrin and Maier, 2003). The net effect of exposure to $\mathrm{Cu}^{2+}, \mathrm{Pb}^{2+}$, $\mathrm{Hg}^{2+}, \mathrm{Ag}^{2+}$ and $\mathrm{Cr}^{2+}$ on the $p, p^{\prime}-\mathrm{DDT}$ degradation by strain MY $83295 \mathrm{~F}$ was thus, reduced biodegradation rates and failure to effectively degrade the $p, p$ '-DDT.

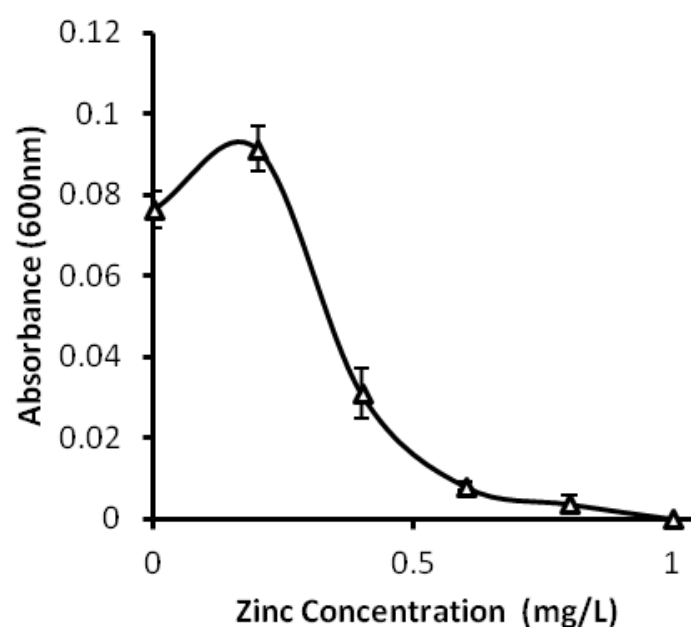

Fig. 5. Effect of $\mathrm{Zn}^{2+}$ concentration on the growth of strain MY $83295 \mathrm{~F}$ in $p, p^{\prime}$-DDT $\left(60 \mathrm{mgL}^{-1}\right)$ enrichment medium. The turbidity of the medium is an index of growth of the isolate in the $p, p$ 'DDT enrichment medium, which was determined spectrophotometrically as optical density (OD) at $600_{\mathrm{nm}}$. The experinments were conducted in triplicate.
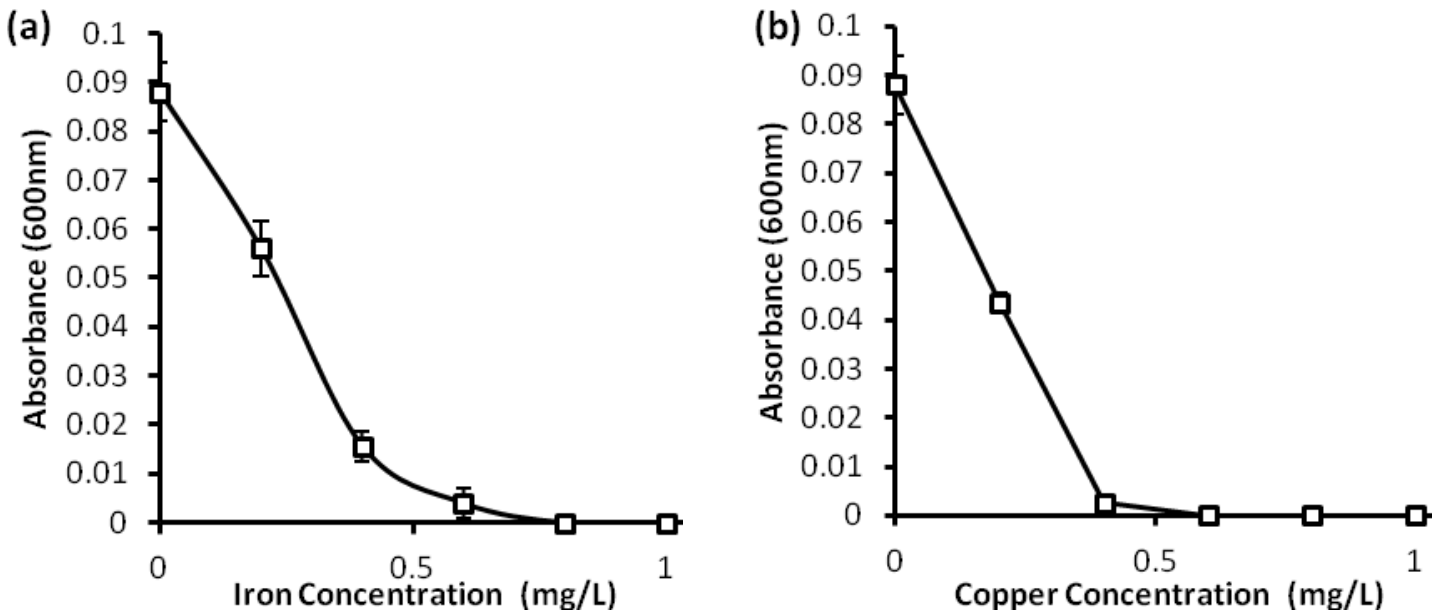

Fig. 6. Effect of $\mathrm{Fe}^{2+}$ (a) and $\mathrm{Cu}^{2+}($ b) concentrations on the growth of strain MY 83295F in $p, p^{\prime}$-DDT(60 $\left.\mathrm{mgL}^{-1}\right)$ enrichment medium. The turbidity of the medium is an index of growth of the isolate in the $p, p$ '-DDT enrichment medium, which was determined spectrophotometrically as optical density (OD) at $600 \mathrm{~nm}$. The experinments were conducted in triplicate. 

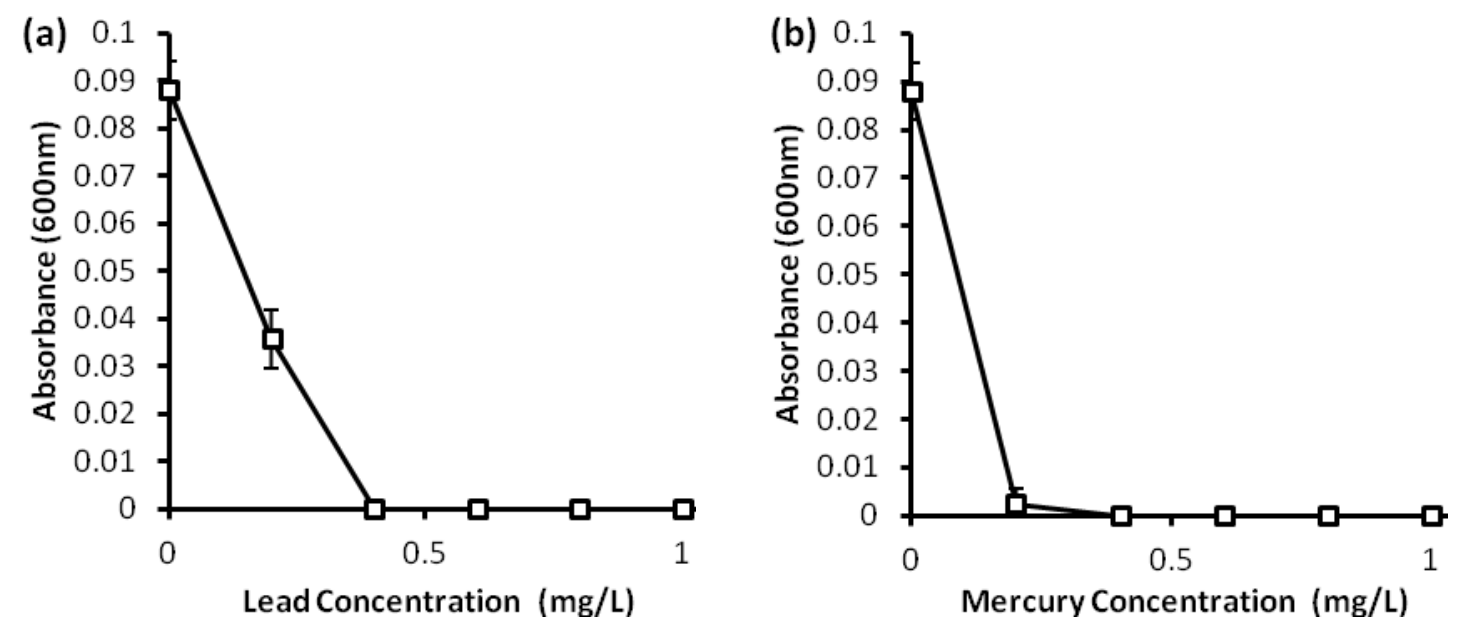

Fig. 7. Effect of $\mathrm{Pb}^{2+}$ (a) and $\mathrm{Hg}^{2+}$ (b) concentrations on the growth of strain MY 83295F in $p$, $p$ 'DDT(60 mgL $\left.{ }^{-1}\right)$ enrichment medium. The turbidity of the medium is an index of growth of the isolate in the $p, p$ '-DDT enrichment medium, which was determined spectrophotometrically as optical density (OD) at $600 \mathrm{~nm}$. The experinments were conducted in triplicate.
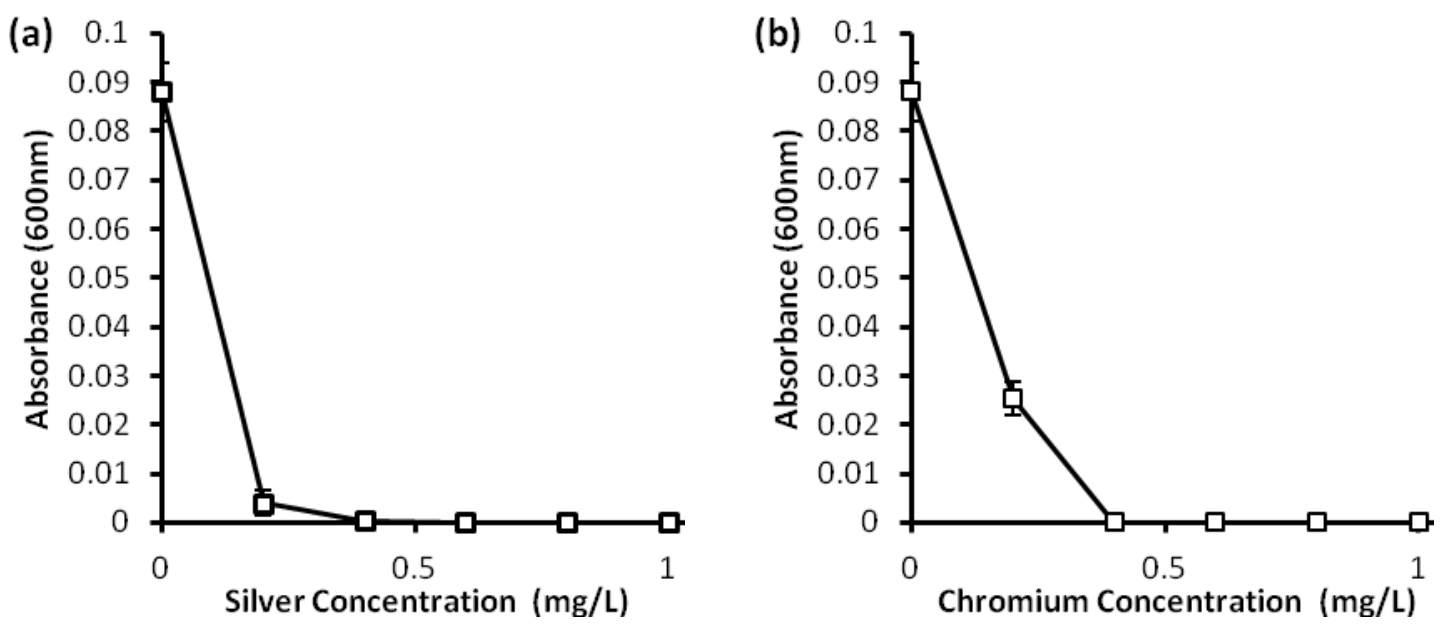

Fig. 8. Effect of $\mathrm{Ag}^{2+}$ (a) and $\mathrm{Cr}^{2+}$ (b) concentrations on the growth of strain MY 83295F in $p$, $p$ 'DDT(60 mgL $\left.{ }^{-1}\right)$ enrichment medium. The turbidity of the medium is an index of growth of the isolate in the $p, p$ '-DDT enrichment medium, which was determined spectrophotometrically as optical density (OD) at $600 \mathrm{~nm}$. The experinments were conducted in triplicate.

\section{Conclusions}

A strain MY $83295 \mathrm{~F}$ of the genus Staphylococcus was isolated from pesticidecontaminated soil. The strain was capable of growing in up to $60 \mathrm{mg} \mathrm{L}^{-1}$ of $p$, $p^{\prime}$-DDT as the sole carbon and energy source at an optimum $\mathrm{pH}$ of 6.5 and optimum temperature of $30{ }^{\circ} \mathrm{C}$ within 120 h. $\mathrm{Zn}^{2+}$ demonstrated a stimulatory effect on the growth of the strain in the $p, p$ 'DDT enrichment medium. However, $\mathrm{Fe}, \mathrm{Cu}$,
$\mathrm{Pb}, \mathrm{Hg}, \mathrm{Ag}$ and $\mathrm{Cr}$ ions showed various patterns of an inhibitory effect on the growth of the strain. Thus, a simultaneous incidence of $p, p$ '-DDT and the inhibitory heavy metals in same environment may alter the $p, p$ '-DDT biodegradation potentiality of the strain. This strain could be a handy tool for the bioremediation of residual $p, p$ '-DDT contaminant. 


\section{Conflict of Interest}

The authors declare that the research was conducted in the absence of any commercial or financial relationships that could be construed as a potential conflict of interest.

\section{References}

1. Abdul Kader M (2019) Domination of pollutant residues among food products of South-East Asian countries. Acta Sci Pharm Sci 3(9):75-79.

2. Aislabie JM, Richards NK, Boul HL (1997) Microbial degradation of DDT and its residues-a Review. New Zealand J Agric Res 48:269-282.

3. Angle JS, Chaney RL (1989) Cadmium resistance screening in nitrilotriacetatebuffered minimal media, Appl Environ Microbiol 55:2101-2104.

4. Asogwa EU, Dongo LN (2009) Problems associated with pesticide usage and application in nigerian cocoa production: a review. African J Agric Res 4:675-683.

5. Baczynski TP, Pleissner $\mathrm{D}$, Grotenuis $\mathrm{T}$ (2010) Anaerobic biodegradation of organochlorine pesticides in soil significance of temperature and availability. Chemosphere 78:22-28.

6. Bao P, Hu ZY, Wnag XJ, Chen J, Ba YX, Hua J, Zhu CY, Zhong M, Wu CY (2012) Dechlorination of p,p'-DDTs coupled with sulfate reduction by novel sulfate- reducing bacterium Clostridium sp. BXM. Environ Pollut 162:303-310.

7. Barragan-Huerta BE, Costa-Pe'rezc C, Peralta-Cruza J, Barrera-Cortes J, EsparzaGarc1'a F, Rodri'guez-Va'zquez R (2007) Biodegradation of organochlorine pesticides by bacteria grown in microniches of the porous structure of green bean coffee. Inter Biodeter Biodeg 59:239-244.

8. Bascomb S, Manafi M (1998) Use of enzyme tests in characterization and identification of aerobic and facultatively anaerobic Gram-positive cocci. Clin Microbiol Rev 11:318-340.

9. Bidlam R, Manonmani HK (2002) Aerobic Degradation of Dichlorodiphenyltrichloroethane (DDT) by Serratia marcescens DT-1P. Pro Biochem 38:49-56.

10. Bussolaro D, Filipak Neto F, Glinksi A, Roche H,Guiloski IC, Mela M, Silva de Assis HC, Oliveira Ribeiro CA (2012) Bioaccumulation and related effects of pcbs and organochlorinated pesticides in freshwater fish Hypostomus commersoni. J Environ Monit 14(8):2154-2163.

11. Cohn BA, Cirillo PM, Terry MB (2019) DDT and breast cancer: prospective study of induction time and susceptibility windows. J Nat Cancer Inst 111(8):803810.

12. Cutright TJ, Erdem Z (2012). Overview of the bioremediation and the degradation pathways of DDT: Review. J Adnan Menderes Univ Agric Faculty, 9(2):39-45.

13. Devi NL, (2020) Persistent Organic Pollutants (POPs): environmental risks, toxicological effects, and bioremediation for environmental safety and challenges for future research. In: Saxena G., Bharagava R. (eds) bioremediation of industrial waste for environmental safety. pp 53-76 Springer, Singapore

14. Fang H, Dong B, Yan H, Tang F, Yu Y (2010) Characterization of a bacterial strain capable of degrading DDT congeners and its use in bioremediation of contaminated soil. J Haz Mat 184:281-289.

15. Gao B, Leu W, Jia WB, Jia LJ., Xu L, Xie J (2011) Isolation and characterization of an Alcaligenes sp. Strain DG-5 capable of degrading DDTs under aerobic conditions. J Environ Sci Health Part B 46:57-263.

16. Ghebremedhin B, layer F, Konig W, Konig B (2008) Genetic classification and distinguishing of Staphylococcus species 
based on the different partial gap, 16S rRNA, hsp60, rpoB, sodA and tuf gene sequences. J Clin Microbiol 46:1019-1025.

17. Guffanti AA, Wei Y, Rood SV, Krulwich TA (2002) An antiport mechanism for a member of the cation di!usion facilitator family: divalent cations efflux in exchange for $\mathrm{K}^{+}$and $\mathrm{H}^{+}$. Mol Microbiol 45:145-153.

18. Hadara T, Takeda M, Kojima S, Tomiyama N (2016) Toxicity and carcinogenicity of dichlorodiphenyltrichloroethane (DDT). Toxicol Res 32(1):21-33.

19. Hong S, Farrence CE (2015) Is it essential to sequence the entire 16S RRNA gene for bacterial identification? American Pharm Rev 18(7):1-7.

20. Hu X, Li S, Cirillo P, Krigbaum N, Tran V, Ishikawa T, La Merill M.A, Jones DP Cohn B (2019) Metabolome wide association study of serum DDT and DDE in pregnancy and early postpartum. Rep Toxicol pil: S0890-6238(18):30588-4.

21. Hug LA, Maphosa F, Leys D, Loffler FE, Smidt H, Edwards EA, Adrian L (2013) Overview of organohalide-respiring bacteria and a proposal for a classification system for reductive dehalogenases. Phil Transact Royal Soc B 368(1616):20120322.

22. Jill E, Clarridge III (2004) Impact of $16 \mathrm{~S}$ rRNA gene sequence analysis for identification of bacteria on clinical microbiology and infectious diseases. Clin Microbiol Rev 17(4):840-862.

23. Kantachote D, Singleton I, McClure N, Naidu R, Megharaj M, Harch BD (2003) DDT resistance and transformation by different microbial strains isolated from DDT-contaminated soils and compost materials, Compost Sci Util 11:300-310.

24. Karmaker A, Dua P, Ghosh C (2016) Biochemical and molecular analysis of Staphylococcus aureau clinical isolate from hospitalized patients. Canadian J Infect Disease Med Microbiol 2016(3):1-7.

25. Khattak MO, Bilal M, Rizwan M, Ahmad S, Meer A, Ullah I (2015) The sensitivity of different phenotypic tests used for detection of Staphylococcus aureus in the coagulase test. J Med Sci (Peshawar) 23(3):125-129.

26. Lovecka P, Pacovska I, Stursa P, Vrchotova B, Kochankova L, Demnerova K (2005) Organochlorinated pesticide degrading microorganisms isolated from contaminated soil. New Biotechnol 32(1):26-31.

27. Mansouri A, Cregut M, Abbes C, Durand MJ, Landoulsi A, Thouand G (2017) The environmental issues of DDT pollution and bioremediation: a multidisciplinary review. Appl Biochem Biotechnol 181(1):309-339.

28. Medehouenou TCM, Ayotte P, Carmichael PH, Kröger E, Verreault R, Lindsay J et al, (2019) Exposure to polychlorinated biphenyls and organochlorine pesticides and risk of dementia, alzheimer's disease and cognitive decline in an older population: a prospective analysis from the Canadian study of health and aging. Environ Health, 18(1):57.

29. Mendes RA, Lima MO, de Deus RJA, Medeiros AC, Faial KCF, Jesus IM, Faial KRF, Santos LS (2019) Assessment of DDT and mercury levels in fish and sediments in the Iriri River, Brazil: distribution and ecological risk, J Environ Sci Health B 9:1-10.

30. Mitra S, Roy P (2010) Molecular identification by $16 \mathrm{~S}$ rDNA sequence of a novel bacterium capable of degrading trichloroethylene. J Biol Sci 10:637-642.

31. Mnif W, Hassine AH, Bouaziz A, Bargeti A,Thomas O, Roig B (2011) Effect of Endocrine Disruptor Pesticides: A Review. Inter J res Pub Health 8:2236-2303.

32. Murata T, Kanao-Koshikawa M, Takamatsu $\mathrm{T}$ (2005) Effects of $\mathrm{Pb}, \mathrm{Cu}, \mathrm{Sb}$, In and $\mathrm{Ag}$ Contamination on the 
Proliferation of Soil Bacterial Colonies, Soil Dehydrogenase Activity, and Phospholipid Fatty Acid Profiles of Soil Microbial Communities. Water, Air Soil poll 164:103-118.

33. Mwangi K, Boga HI, Muigai AW, Kiiyukia C, Tsanuo MK (2010) Degradation of Dichlorodiphenyltrichloroethane (DDT) by Bacterial Isolates from Cultivated and Uncultivated Soil. African J Microbiol Res 4 (3):185-196.

34. Nadeau LJ, Sayler GS, Spain, JC (1998). Oxidation of 1,1,1-trichloro-2,2-bis(4chlorophenyl) Ethane (DDT) by Alcaligenes eutrophus A5. Arch Microbiol 171:44-49.

35. Naushad S, Barkema HW, Luby C, Condas LAZ, Nobrega DB, Carson DC, Buck, JD (2016) Comprehensive phylogenetic analysis of bovine non-aureus Staphylococci species based on wholegenome sequencing. Front Microbiol 7:2016.01990.

36. Nies DH (1999) Microbial Heavy-Metal Resistance. Appl Microbiol Biotechnol 51:730-750.

37. Nies DH (2003) Efflux-mediated heavy metal resistance in prokaryotes. FEMS Microbiol Rev 27: 313-339.

38. Ogbeide O, Tongo I, Ezemonye L (2015) Risk Assessment of Agricultural Pesticides in Water,Sediment, and Fish from Owan River, Edo state, Nigeria, Environ Monit Assess 187:654-666.

39. Pan X, Lin D, Zheng Y, Zhang Q, Yin, Y, Cai L, Fang H, Yu Y (2016). Biodegradation of DDT by Stenotrophomonas sp. DDT-1: characterization and genome functional analysis. Sci Reports, 6:21332.

40. Pan X, Xu T, Xu H, Fang H, Yu Y (2017) Characterization and genome functional analysis of the DDT-degrading bacterium
Ochrobactrum sp. DDT-2, Sci Total Environ 592:593-599.

41. Pant G, Mistry SK, Sibi G (2013). Isolation, identification and characterization of p, p-DDT degrading bacteria from soil. J Environ Sci Technol 6(8):180-187.

42. Piazza MJ, Urbanetz AA (2019) Environmental toxins and the impact of other endocrine disrupting chemicals in women's reproductive health. JBRA Assisted Rep 23(2):154-164.

43. Reineke W, Mandt C, Kaschabek SR Pieper DH (2011) Chlorinated Hydrocarbon Metabolism. In: eLS. John Wiley and Sons, Ltd: Chichester. pp. 1-17.

44. Roy RP, Bahadur M, Barat S (2013) Isolation, identification and antibiotic resistance of Aeromonas spp. and Salmonella spp. from the fresh water loach, Lepidocephalichthys guntea and water of Terai River Lotchka, West Bengal, India. Zoologica Poloniae 58:5-17.

45. Sandrin TR, Maier RM (2003) Impact of metals on the biodegradation of organic pollutants. Environ Health Pers 111(8): 1093-1101.

46. Sanger F, Nicklen S, Coulson AR (1977) DNA Sequencing with chain-terminating inhibitors. Biochem 74(12):5463-5467.

47. Sangwan P, Kovac S, Kathryn ERD, Sait M, Peter HJ (2005) Detection and cultivation of soil Verrucomicrobia. Appl Environ Microbiol 2005:8402-8410.

48. Saruta K, Matsunaga T, Kono M, Hoshina S, Ikawa S, Sakai O, Machida K (1997) Rapid identification and typing of Staphylococcus aureus by nested PCR amplified ribosomal DNA spacer region. FEMS Microbiol Letters, 146:271-278.

49. Schmidt TM, Delong EF, Pace NR (1991). Analysis of a marine picoplankton community by 165 rRNA gene cloning and sequencing. J Bacteriol 178:4871-4878. 
50. Sheldon M, Pinion JC, Klyza J, Zimeri A (2019) Pesticide contamination in Central Kentucky urban honey: a pilot study. J Environ Health 82(1):8-13.

51. Stackebrandt E, Goebel BM (1994) Taxonomic note: a place for DNA-DNA reassociation and $16 \mathrm{~S}$ rRNA sequence analysis in the present species definition in bacteriology. Inter J Sys Bacteriol 44:846849.

52. Suryawati B (2018) Zinc homeostasis mechanism and its role in bacterial virulence capacity. The $8^{\text {th }}$ Annual Basic Science International Conference. AIP Conference Proceedings, Universitas Brawijaya, Indonesia. 2021:070021-1070021-7.

53. Takahashi T, Satoh I, Kikuchi N (1999) Phylogenetic relationships of 38 taxa of the genus Staphylococcus based on 16S rRNA gene sequence analysis. Inter $\mathbf{J}$ Sys Bacteriol 49:725-728.

54. Tamura K, Stecher G, Peterson D, Filipski A, Kumar S (2013) MEGA6: Molecular Evolutionary Genetics Analysis version 6.0. Mol Biol Evol 30(12):2725-2729.

55. Truong KM, Cherednichenko G, Pessah IN (2019) Interactions of dichlorodiphenyltrichloroethane (DDT) and dichlorodiphenyldichloroethylene (DDE) with skeletal muscle ryanodine receptor type 1. Toxicol Sci 170(2):509-524.

56. UNEP, (2019) DDT expert group and its report on the assessment of scientific, technical, environmental and economic information on the production and use of DDT and its alternatives for disease vector control. Conference of the Parties to the Stockholm Convention on Persistent Organic Pollutants Ninth meeting, Geneva, 29 April-10 May 2019.

57. Wang B, Liu W, Liu X, Franks AE, Teng Y, Luo Y (2017) Comparative analysis of microbial communities during enrichment and isolation of DDT-degrading bacteria by culture-dependent and - independent methods. Sci Total Environ 590-591:297303.

58. Xie H, Zhu L, Wang, J (2018) Combined treatment of contaminated soil with a bacterial Stenotrophomonas strain DXZ9 and ryegrass (Lolium perenne) enhances DDT and DDE remediation. Environ Sci Pollut Res 25:31895-31905.

59. You G, Sayles GD, Kupferle MJ, Kim IS, Bishop PL (1996) Anaerobic DDT biotransformation: enhancement by application of surfactants and low oxidation reduction potential. Chemosphere 32:22692284.

60. Yu X, Yu RQ, Zheng X, Zhan F, Sun X, Wu Y (2019) DDT exposure induces cell cycle arrest and apoptosis of skin fibroblasts from Indo-Pacific Humpback dolphin via mitochondria dysfunction. Aqua Toxicol 213:105229. 